\title{
Release of Heparin-like Substance and Histamine from Basophilic Leucocytes Separated by Counterflow Centrifugation Elutriation
}

\author{
Yoshiro TANIZAKI, Michiyasu SUdo, Hikaru KITANI, \\ Kazuhisa KAWAUCHI, Takashi MIFUNE*, Kiyoshi TAKAHASHI* \\ and Ikuro KIMURA*
}

\begin{abstract}
Separation of basophilic granulocytes from peripheral blood was carried out by counterflow centrifugation elutriation using a JE-6B roter. The release of histamine and heparin-like substance from basophilic leucocytes was estimated in healthy and asthmatic subjects. 1. The number of basophils was maximal $\left(0.74 \times 10^{5}\right)$ at a flow rate of $4.5 \mathrm{ml} / \mathrm{min}$, and the purity reached a peak $(11.8 \pm 2.0 \%)$ at a flow rate of 9 $\mathrm{ml} / \mathrm{min}$. 2. The content of histamine paralleled the number of basophils in each fraction. 3 . The release mechanism of histamine induced by anti-IgE was similar to that of the heparin-like substance. 4 . The release of histamine and the heparin-like substance was significantly higher in atopic asthmatics than in non-atopic cases.
\end{abstract}

Key words: Basophils, Bronchial asthma, Anti-IgE, Cell purification

Several attempts have been made to purify basophilic granulocytes from peripheral blood (1-5). However, basophilic granulocytes are very fragile and easily lose their activity. In the purification of peritoneal mast cells, it has been reported that purification of the cells through any density media results in a loss of 50 to $80 \%$ of the IgEreceptor binding activity (6). It is very important that basophil purification is carried out under physiological conditions without any density media to prevent cell membrane damage.

By analyses of allergic reactions, the release of chemical mediators from tissue mast cells and blood basophils has been reported (7-9). Chemical mediators such as leukotrienes, prostaglandins and platelet activating factor are newly generated in these cells, and are released from the cells when the cells are stimulated with antigen and anti-IgE. Histamine and heparin-like substance are stored in the granules of the cells and released, and in many cases are accompanied by degranulation (10-15).

In the present study, separation of basophils from peripheral blood was carried out by counterflow centrifugation elutriation, and histamine and the heparin-like substance contained in the cell granules were released after stimulation with anti-IgE.

\section{SUBJECTS AND METHODS}

Subjects: Twenty patients with bronchial asthma (10 atopic asthmatics aged 12 to 61 years and 10 nonatopic cases aged 20 to 80 years), and 8 healthy subjects aged 20 to 41 years, were examined in the present study.

Cell suspension: Basophils were separated by counterflow centrifugation elutriation using a JE-6B roter (Beckman) $(16,17)$. Venous blood $(17.5 \mathrm{ml})$

From Division of Medicine, Misasa Medical Branch, Okayama University Medical School, Tottori and *Second Department of Medicine, Okayama University Medical School, Okayama

Received for publication July 17, 1989; Accepted for publication May 29, 1990

Reprint requests should be addressed to Yoshiro Tanizaki, MD, Division of Medicine, Misasa Medical Branch, Okayama University Medical School, 827 Yamada, Misasa, Tottori 682-02, Japan 
was drawn into a test tube containing $2.5 \mathrm{ml}$ of 0.1 $M$ EDTA. The test tube was incubated for $1 \mathrm{~h}$ at room temperature, and centrifuged for $8 \mathrm{~min}$ at $500 \mathrm{rpm}$. After the supernatant was removed, the precipitate was transferred into the roter with the buffer ( $\mathrm{pH} 7.2$, osmotic pressure $325 \mathrm{mOsm} / \mathrm{kg}$ $\mathrm{H}_{2} \mathrm{O}$ ) containing $1 / 10 \mathrm{M}$ phosphate buffer, $0.14 \mathrm{M}$ $\mathrm{NaCl}$ and $2 \%(\mathrm{w} / \mathrm{v})$ bovine serum albumin (16) at a flow rate of $4.5 \mathrm{ml} / \mathrm{min}$. The sample flowing out of the roter for $8 \mathrm{~min}$ was collected into a test tube. After the roter was washed out with the buffer for $10 \mathrm{~min}$, the procedure for cell separation was started at a flow rate of $6 \mathrm{ml} / \mathrm{min}$. The flow rate was increased by $1 \mathrm{ml}$ per $4 \mathrm{~min}$, followed by the collection of cells into a test tube. The final flow rate was $15 \mathrm{ml} / \mathrm{min}$. The experiment was performed under $4^{\circ} \mathrm{C}$ at $2000 \mathrm{rpm}$.

Cell differentiation: Cells collected in each fraction were stained with a staining solution for the direct count of eosinophils and basophils (18), and differentiated in a Fuchs-Rosenthal chamber.

The viability of basophils separated by the method was assessed by Tryphan blue exclusion, by the direct counting method (18) and under phasecontrast microscopic observation $(10,15)$.

Release of histamine and heparin-like substance

Cells containing basophils $\left(0.3-3.0 \times 10^{5} / \mathrm{ml}\right)$ were suspended in Tyrode's solution $(1 \mathrm{ml})$. To the cell suspension was added $0.1 \mathrm{ml}$ of various concentrations of anti-human IgE (Behringwerke). The mixed solution was incubated at $37^{\circ} \mathrm{C}$ for 45 min. After the incubation, the reaction was stopped by transferring into an ice bath.

Estimation of histamine

The content of histamine was estimated by a previously described method $(8,9)$. After the reaction was stopped, the cells were separated by centrifugation at $1500 \mathrm{rpm}$ for $20 \mathrm{~min}\left(4^{\circ} \mathrm{C}\right)$. The histamine content of the cells and the supernatant fluid was analyzed by perchloric acid precipitation and assayed by an automated spectrofluorometric histamine analysis system (Technicon) $(19,20)$.

Estimation of heparin-like substance

The content of heparin-like substance in the supernatant fluid after the cells were separated by centrifugation was estimated by the change in spectrophotometric absorbancy after formation of the heparin-Azure complex (21).

\section{RESULTS}

\section{Frequency of leucocytes in each fraction}

The average number of total cells from 5 healthy subjects separated by counterflow centrifugation elutriation was maximal $\left(5.64 \times 10^{6}\right)$ at a flow rate of $4.5 \mathrm{ml} / \mathrm{min}$. Thereafter the number decreased with a flow rate of 6 to $10 \mathrm{ml} / \mathrm{min}$, and increased again with a flow rate of 11 to $14 \mathrm{ml} / \mathrm{min}$. The total number of cells separated at a flow rate of 6 to 15 $\mathrm{ml} / \mathrm{min}$ was $11.53 \times 10^{6}$. The recovery rate of total cells from venous blood was $60.6 \%$ (Fig. 1).

The frequency of various leucocytes collected into each fraction was examined. The frequency of lymphocytes was higher at a low flow rate (4.5 to $8 \mathrm{ml} / \mathrm{min}$ ), and gradually decreased as the flow rate

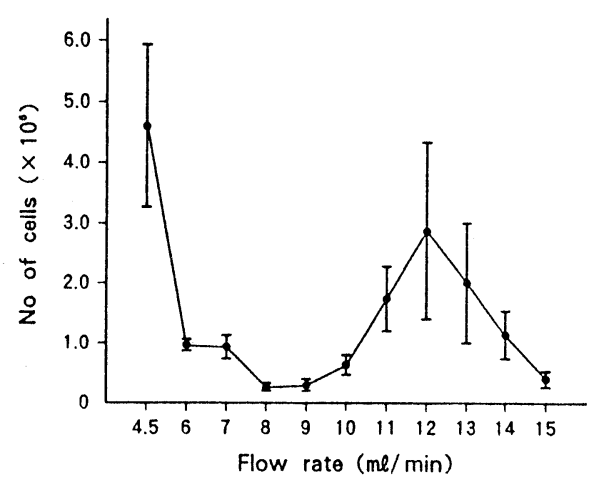

Fig. 1. Number of cells separated in each fraction.

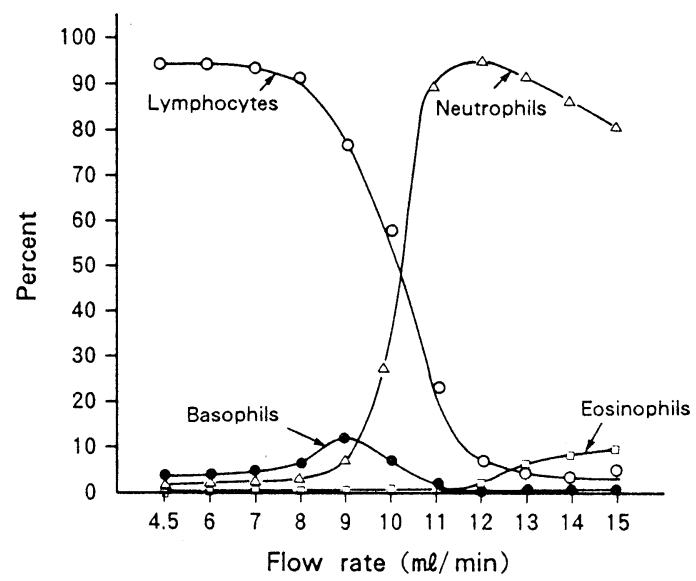

Fig. 2. Frequency of leucocytes separated into each fraction; lymphocytes; $(\mathrm{O}-\mathrm{O})$, neutrophils; $(\triangle \triangle \Delta)$, basophils; ( $\bigcirc$ ), eosinophils; $(\square-\square)$ 


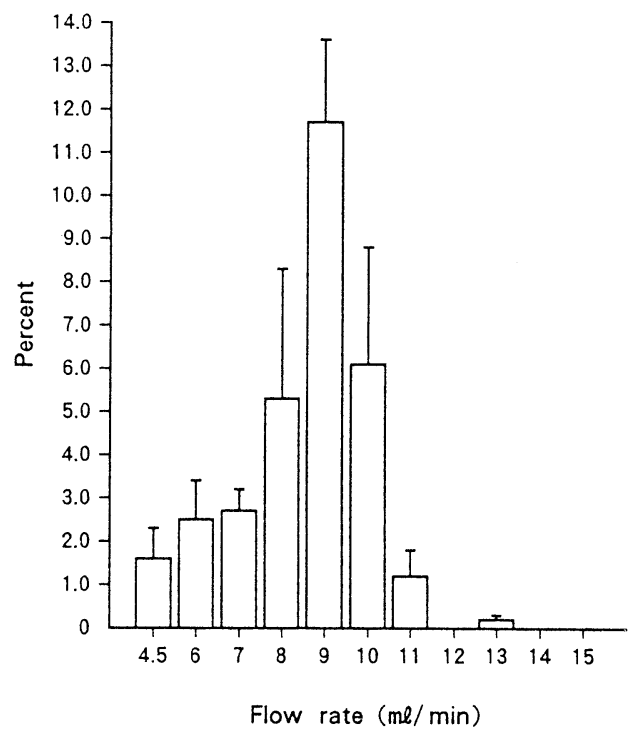

Fig. 3. Purity of basophils separated into each fraction.

increased. The frequency of neutrophils was low at a low flow rate, markedly increased at a flow rate of $10 \mathrm{ml} / \mathrm{min}$, and reached a peak at a flow rate of $13 \mathrm{ml} / \mathrm{min}$. Few eosinophils were observed at a low flow rate; the frequency increased at a flow rate of $12 \mathrm{ml} / \mathrm{min}$ or higher (Fig. 2).

The purity of basophils $(0.9 \pm 0.5 \%$ in the peripheral blood) gradually increased at a low flow rate and reached a peak $(11.8 \pm 2.0 \%)$ at a flow rate of $9 \mathrm{ml} / \mathrm{min}$. The number of basophils was maximal $\left(0.74 \times 10^{5} /\right.$ fraction $)$ at a flow rate of $4.5 \mathrm{ml} / \mathrm{min}$. The change in the number of basophils was similar to the change in the purity of the cells, which was higher at a higher flow rate than at $4.5 \mathrm{ml} / \mathrm{min}$ (Fig. 3).

The viability of basophils was greater than $95 \%$ in all fractions, and degranulation was not observed in any basophils by the direct counting method (18); the cells well moved under phase-contrast microscopic observation $(10,15)$. No differences in these findings for basophils were observed among the fractions.

\section{Histamine content of each fraction}

The content of histamine in each fraction paralleled the number of basophils collected into the

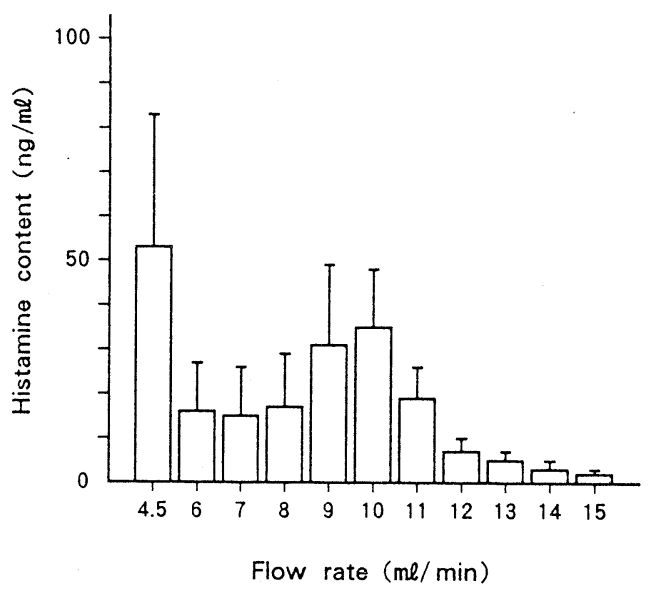

Fig. 4. Histamine content contained in each fraction.

fraction. A larger histamine content was observed in the fractions at a flow rate of 4.5 and 9-10 $\mathrm{ml} / \mathrm{min}$. The content of histamine was low at a flow rate of $12 \mathrm{ml} / \mathrm{min}$ or higher (Fig. 4). As determined from the results described above, the cells collected at a flow rate of $4.5 \mathrm{ml} / \mathrm{min}$ for $8 \mathrm{~min}$ were applied for the experiments of histamine release, and the cells separated at a flow rate of 6 to $11 \mathrm{ml} / \mathrm{min}$ were used for the experiments of the release of the heparin-like substance.

\section{Dose-response curves of histamine and heparin- like substance induced by anti-IgE}

The release of histamine from leucocytes of 4 patients with atopic asthma showed a peak at concentrations of $10^{2}$ to $10^{3}$-fold dilutions of anti-IgE. The maximum release of heparin-like substance was also observed at concentrations of $10^{2}$ to $10^{3}$-fold anti-IgE dilutions. The release mechanism of both mediators seemed to be similar when the cells were stimulated with anti-IgE (Fig. 5).

\section{Release of histamine and heparin-like substance in patients with bronchial asthma}

The patients with bronchial asthma were divided into two groups; atopic and non-atopic. The maximum release of both mediators by anti-IgE between the two groups was compared. The maximum histamine release percentage was $36.6 \pm 11.1 \%$ in patients with atopic asthma and 
Heparin-like Substance and Histamine
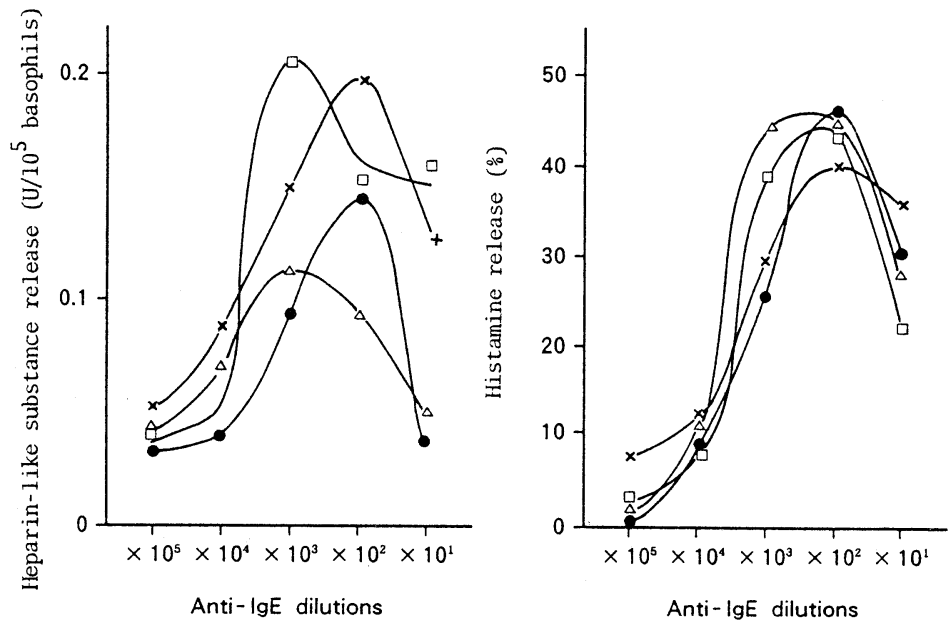

Fig. 5. The release of heparin-like substance and histamine from basophils of atopic asthmatics, induced by anti-IgE.

$13.6 \pm 8.1 \%$ in cases with non-atopic asthma $(23.6 \pm 8.1 \%$ in healthy subjects). There was a significant difference in histamine release between the two asthma groups $(\mathrm{p}<0.05)$. The maximum release of heparin-like substance was $0.078 \pm 0.053$ $\mathrm{U} / 10^{5}$ basophils in atopic asthmatics and $0.035 \pm 0.021 \mathrm{U} / 10^{5}$ basophils in non-atopic asthmatics $\left(0.026 \pm 0.028 \mathrm{U} / 10^{5}\right.$ basophils in healthy subjects). A significant difference was present in the release of heparin-like substance between atopic and non-atopic asthmatics $(p<0.05)$ (Fig. 6).
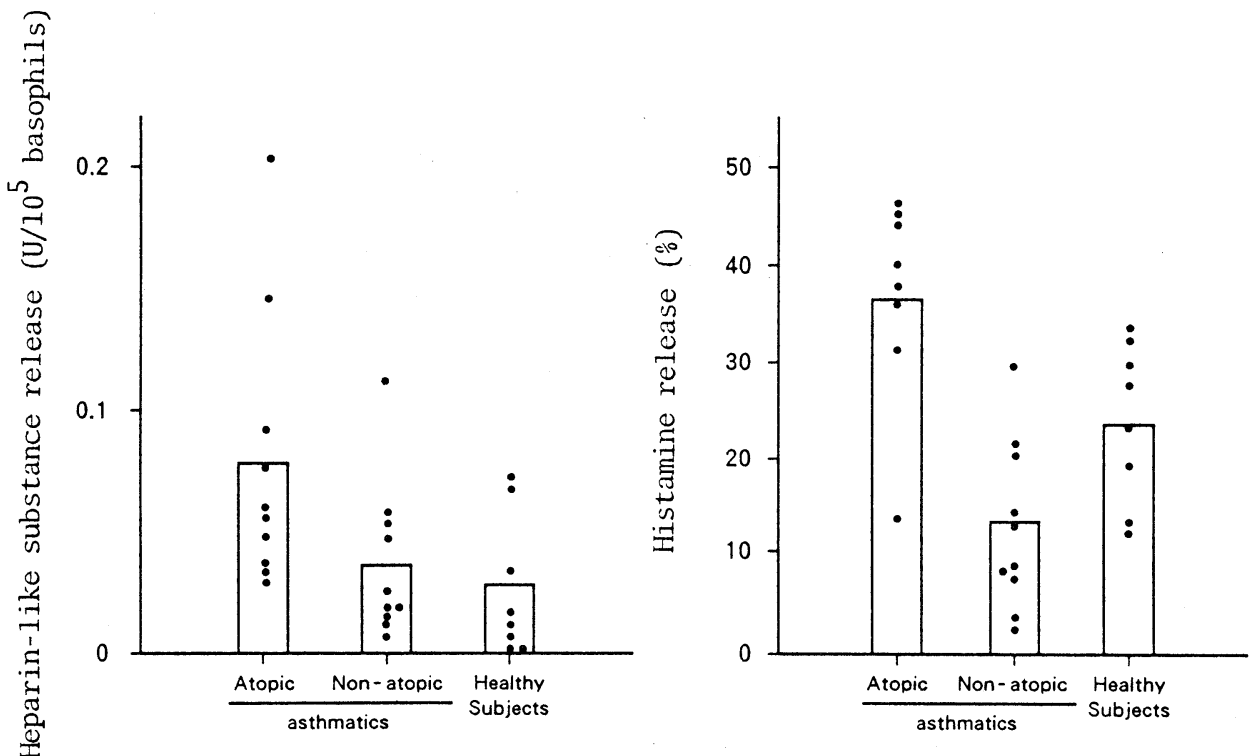

Fig. 6. The release of heparin-like substance and histamine in healthy subjects, and atopic and non-atopic asthmatics. 


\section{DISCUSSION}

Histamine and heparin-like substance were contained in the granules of tissue mast cells and blood basophils. The release of both mediators is usually accompanied by degranulation of the cells (10-15). It is well known that observation of histamine release from leucocytes by stimulation with antigen and anti-IgE is valuable for diagnosis and treatment of allergic diseases $(19,20,22-24)$.

Basophils and mast cells release mediators, which are divided into two groups; newly generated mediators (leukotrienes, prostaglandins, platelet activating factor, etc) and preformed mediators (histamine, heparin-like substance, neutrophil chemotactic factor, eosinophils chemotactic factor, etc) when the cells are stimulated with antigen. In the present study, the release mechanism of preformed mediators contained in the granules was observed in basophils separated under physiological conditions, using counterflow centrifugation elutriation.

There are some difficulties in the observation of the release of chemical mediators from basophils. First, a sufficient number of basophils of high purity is necessary for the experiments of the release of heparin-like substance, although the release of histamine can be more easily observed even in low purity cases. The previously developed (4) separation method of basophils using Ficoll-Conray was not suitable for the experiments of the release of the heparin-like substance due to the low number of basophils in spite of the high purity. Second, basophils and mast cells are very fragile and the cell membrane is easily damaged during separation procedures of the cells $(6,25)$. Therefore, the separation of basophils should be performed under physiological conditions.

In the present study, basophils were separated by counterflow centrifugation elutriation using a JE-6B roter. It was confirmed by microscopic observation that by this method basophils could be separated without cell membrane damage. Basophils which separated into fractions at a flow rate of $4.5 \mathrm{ml} / \mathrm{min}$ (fraction with large number of basophils) were used for the experiment of histamine release and those separating at a flow rate of $6-11 \mathrm{ml} / \mathrm{min}$ (fraction with high purity basophils), for the release of heparin-like substance. The release of both mediators in these fractions could be estimated by a spectrofluorometric method for histamine $(8,9)$ and a heparin-Azure complex formation method for the heparin-like substance (21). The results demonstrated that histamine and the heparin-like substance, which are contained in the granules of the cells, are released similarly when the cells are challenged with anti-IgE. It is not clear whether the muco-polysaccharide contained in basophil granules is heparin or some other substance.

The release of both mediators induced by antiIgE was different in atopic and non-atopic asthmatics. More, histamine and heparin-like substance was released in the patients with atopic asthma than in the cases with non-atopic asthma. The results suggest that separation of basophils by counterflow centrifugation elutriation is suitable when available for clinical and experimental studies on allergic and immunological reactions in which the cells participate, and also that the IgE-mediated reaction is more dominant in atopic asthmatics than in nonatopic cases.

\section{REFERENCES}

1) Wilson $A B$, Coombs RR. Passive sensitization of tissue cells. IV. Guinea-pig antibodies cytophilic for basophils and Kurloff cells. Int Arch Allergy Appl Immunol 40: 19, 1971.

2) Day RP. Basophil leucocytes separation from human peripheral blood: A technique for their isolation in high purity and high yield. Clin Allergy 2: 205, 1972.

3) Dvorak HF, Selvaggio SS, Dvorak AK, Colvin RB, Lean D, Pypysc SS. Purification of basophilic leucocytes from guinea pig blood and bone marrow. J Immunol 113: 1619, 1974.

4) Tanizaki Y, Takahashi K, Hosokawa M, et al. Purification of basophilic leucocytes from peripheral blood. Acta Haematol Jpn 41: 705, 1978.

5) Macglashan DW, Lichtenstein LM. The purification of human basophils. J Immunol 124: 2519, 1980.

6) Coutts SM, Nehring RE Jr, Jariwala NU. Purification of rat peritoneal mast cells: Occupation of IgE-receptors by IgE prevents loss of the receptors. J Immunol 124: 2309, 1980.

7) Ishizaka T. Analysis of triggering events in mast cells for immunoglobulin E-mediated histamine release. J Allergy Clin Immunol 67: 90, 1981.

8) Tanizaki Y, Komagoe H, Morinaga H, Kitani H, Goda Y, Kimura I. Allergen- and anti-IgE-induced histamine release from whole blood. Int Arch Allergy Appl 
Immunol 73: 141, 1984.

9) Tanizaki $Y$, Komagoe H, Sudo M, et al. Basophil histamine release induced by Candida albicans. Relation to specific IgE and IgG antibodies. Jpn J Allergol 34: $422,1985$.

10) Kimura I, Tanizaki $Y$, Sasaki $Y$. In vitro antigeninduced increase in motility and degranulation of basophilic granulocytes from atopic asthmatics, studied by microscopic motion pictures. Int Arch Allergy Appl Immunol 75: 250, 1984.

11) Hastie $R$. The antigen-induced degranulation of basophil leucocytes from atopic subjects, studied by phase-contrast microscopy. Clin Exp Immunol 8: 45, 1971.

12) Ishizaka $T$, Tomioka $K$, Ishizaka K. Degranulation of human basophil leucocytes by anti-IgE antibody. J Immunol 106: 705, 1971.

13) Cochrane DE, Douglas WW. Calcium-induced extrusion of secretory granules (exocytosis) in mast cells exposed to $48 / 80$ or ionophore A23187. Proc Natl Acad Sci USA 71: 408, 1974.

14) Hino RH, Lau CKH, Read GW. The site of action of the histamine releasor compound $48 / 80$ in causing mast cell degranulation. J Pharmacol Exp Ther 200: 658, 1977.

15) Tanizaki Y, Matsuoka T, Maeda M, Takahashi K, Kimura I. Microscopic observation on degranulation of blood basophilic leucocytes: Relationship to different responses to antigen. Acta Haematol Jpn 48: 1357, 1985.

16) Jemionek JF, Contreras TJ, French JE, Shields LJ. Technique for increased granulocyte recovery from human whole blood by counterflow centrifugation elutriation. I. In vitro analysis. Transfusion 19: 120, 1978.

17) Glick D, Redlich DV, Juhos ET, Mcewen CR. Separation of mast cells by centrifugal elutriation. Exp Cell Res 65: 23, 1971.

18) Kimura I, Moritani Y, Tanizaki Y. Basophils in bronchial asthma with reference to reagin-type allergy. Clin Allergy 3: 195, 1973.

19) Siraganian RP. Automated histamine release. A method for in vitro allergy diagnosis. Int Arch Allergy Appl Immunol 49: 108, 1975.

20) Siraganian RP, Brodsky MJ. Automated histamine analysis for in vitro allergy testing. I. A method utilizing allergen-induced histamine release from whole blood. J Allergy Clin Immunol 57: 525, 1976.

21) Parekh AC, Glick D. Studies in histochemistry. XV. Heparin and hexosamine in isolated mast cells: Determination, intracellular distribution, and effects of biological state. J Biol Chem 237: 280, 1961.

22) Radermecker MF. Allergen-induced histamine release from whole blood. Clinical evaluation. Int Arch Allergy Appl Immunol 63: 415, 1980.

23) Assem ESK, Attallah NA. Increased release of histamine by anti-IgE from leucocytes of asthmatic patients and possible heterogeneity of IgE. Clin Allergy 11: 367, 1981.

24) Tanizaki $Y$, Komagoe $H$, Sudo $M$, et al. Reactivity of sensitized human basophils, as expressed by histamine release. Jpn J Allergol 33: 463, 1984.

25) Tanizaki Y, Townley RG. Effect of BSA on $\mathrm{Ca}^{2+}$ influx in mast cells stimulated by ovalbumin. Int Arch Allergy Appl Immunol 70: 143, 1984. 